The point of the feasibility study was not to find the ultimate solution of the wastepaper problem, but to get an overview of the environmental impact of large-scale recycling of paper products. It shows clearly that simply recycling as much as we can is not the answer to our environmental problems. Before we commit ourselves to large-scale programmes for recycling of paper products, we need to do more research into the links between recycling, energy consumption, gaseous emissions, and other associated environmental effects. These interrelationships are complex, and they are not always obvious.

Although our study was limited to the recycling of paper products in Western Europe, the findings raise questions about the wisdom of a blind commitment to full recycling of any product or material: in the search for environmental sustainability, recycling is an important tool, but it is not a cure-all. Table I indicates trends with increased recycling of paper. A book elaborating on the results of this study, to be entitled Environmental Impacts of Waste Paper Recycling: A Feasibility Study, will be published by Earthscan Publications Ltd, London, England, UK in the spring of 1993.

STEN NILSSON, Leader
Forestry and Climate Change Project
International Institute for Applied Systems
Analysis (IIASA)
A-2361 Laxenburg
Austria.

\title{
Trapnell Fund for Environmental Field Research in Africa
}

$\mathrm{T}$ he University of Oxford invites applications for support for field-based research concerned with the African environment, with reference to all or any of the following aspects of non-managed ecosystems:

(a) Local climatic variation and geomorphology;

(b) Pedology, soil biology, and soil conservation;

(c) The history, composition, and successional phases, of the vegetation, and the conservation of indigenous forests; and

(d) The carrying capacity of land for human populations.

All other considerations being equal, preference may be given to proposals involving observational and empirical field research into the ecological aspects either of soils or of indigenous forests and woodlands, in the tropical region, and, in the case of studies of the carrying capacity of land, to proposals examining the ecology and current carrying capacity for pastoral and subsistence land-use.

Grants will be awarded either for field research in Africa, or for research in Oxford based upon field-work or previous field-based recording in Africa. Awards at present will normally be of up to approximately $£ 5,000$ in value. Applications for matching funds would be particularly welcome, i.e. where partial support for a project or studentship has already been obtained from some other source or sources.
Applicants must be graduates of British or African universities and must either be working for a research degree of the University of Oxford, or hold a postdoctoral position at the University. Applications should consist of a curriculum vitae, evidence of graduation, a summary of the research proposal not exceeding 4 sides of A4 paper in length, a full breakdown of the cost involved with details of the amount sought and, if appropriate, of other support obtained, and the names and addresses of two academic referees. Those seeking support for a project on the basis of which they hope to be accepted to read for a research degree at Oxford, should note that they must apply separately for admission in the usual way. They should also note that the awards are unlikely to cover the costs of fees or to provide a maintenance grant.

Applications and queries about the scheme should be addressed to the undersigned Dr P.R. Gambles. There is no application form, but please note that the closing date for receipt of applications is 1 MARCH 1993.

\section{Peter R. Gambles University Offices Wellington Square Oxford OXI $2 J D$ England, UK.}

\section{Symposium Marking Opening of IUCN's New Building*}

T his Symposium underlined a message from its latest General Assembly, namely that IUCN should play a greater role than hitherto in advocacy — not just in devising and trying out good policies but by arguing their case in the corridors of power. Thus IUCN should take the role of 'influencing individual and public decision-making' into its mission. Also, there must be improved integration between the various parts of IUCN's programmes; inter-sectoral coordination will be particularly important in such tasks as advising on the implementation of the UN Convention on Biodiversity.

In developing its programme, IUCN must mobilize its membership more effectively and make sure that members are involved as partners in IUCN work wherever possible. The Union must continue the shift from successful field projects to (a) policy analysis and provision of policy tools, (b) institution-building, and (c) provision of specialist services.

The system of governance of IUCN should be reviewed, it having been suggested that the General Assembly is no longer sufficient as a forum for debating and defining policy but may well need to be buttressed by regional assemblies. The Council also needs reviewing, with Regional Councillors keeping in touch with the membership they represent, and funds being provided where necessary to ensure this. National and Regional Committees would be one possible way of achieving such links.

While IUCN must treat governmental and NGO members even-handedly, stronger partnerships should be built with the NGO membership, and more global partnerships be embraced and invigorated. Whether the Union can develop an effective link with the UN Commission for Sustainable Development will depend on the precise form in which the Commission is constituted, and the extent to which the effectiveness of ECOSOC, its parent body, is increased. For IUCN's involvement to be worth-while, there must be an opportunity for real partnership.

The Ecosystem Conservation Group, as an informal discussion group of the UN agencies concerned with sustainable development and environmental conservation and involving major environmental bodies such as IUCN, WWF, and WRI, has great potential value, but needs to be made more effective. It could be used to discuss the scope for joint action, for example in shared topics such as 